\title{
Improvement of Students' Ability on Statistical Software Application (Public Service on Islamic Student for Early Childhood Education Program)
}

\author{
Reflianto \\ Universitas Negeri Malang \\ Malang, Indonesia \\ reflintomuslim@gmail.com
}

\begin{abstract}
The aim of this project is to improve Islamic Student for Early Childhood Education Program mastering in using statistical software program of SPSS. This study is Community-Based Research conducted in The College of Syekh Burhanuddin Pariaman and in Diniyah Putri Padang Panjang. It took four months started from September to December 2015 with the target islamic student totally 40 students who coming from 5 Private Islamic College all arround West Sumatra. The data analysis used statistical technique "frequency distribution, qualitative and quantitative analysis by using independent t-test. Results showed that the public service plays an important role in accelerating the science skills of SPSS for Islamic student.
\end{abstract}

Keywords-acceleration; islamic student; statistical software application

\section{INTRODUCTION}

The project is aimed to help students islam early childhood education who studied at the College of Syech Burhanuddin Pariaman to be able to run the application of statistical software and mastery of statistical science in depth. During this time the Islamic education student for early childhood is good enough to follow the course of statistics, but due to time constraints the course, they do not get guidance workshop on campus Statistical Software is good and comprehensive. In addition to be a training / workshop held Statistical Software college campuses and generally incur training costs are quite expensive, which for those who come from low income, of course this is very burdensome. This is what causes a lot of students from low-income families who can not gain access statistical software training compared to other students who came from middle-income families to the top.

Currently the biggest obstacle faced by students of Islamic education for early childhood from lowincome families in the College Syech Burhanuddin Pariaman is backward in technology mastering statistics, although the statistical calculations of dominance theory they are good enough. This is the background why this research is more dominant in College of Syech Burhanuddin Pariaman more qualitative research without data processing and inferential statistical testing. Whereas in Islamic education, Tarbiyah which seeks to improve the graduates to be a teacher who is superior, able to solve various problems in learning through research and empirical analysis to prove their relevance, relationship and effect between the various variables in learning activities with other variables either internal variable (self students themselves) as well as external variables (teachers, facilities, school facilities, etc.)

Our survey in 2014, a total of 420 student-SB STIT Pariaman are students who have a background in schools $(95 \%)$ were more religious than mastery of statistical sciences[1], Dropping students of Islamic education in the early childhood to understanding of statistics and statistical software applications in STIT Syech Burhanuddin Pariaman due to lack of their involving in the statistical software training/workshop, because the cost is quite expensive for them. When was expected from research methodology and statistics subject in the classroom, not much help them to be able to master this skill, this is due to time constraints and the number of lectures to be given, so that training is not sufficient. For that we need a special training program for islamic students of early childhood education in order to master the basic science through statistical software application training programs for students of Islamic education in the early childhood of College of Syech Burhanuddin Pariaman include SPSS and Amos training.

To overcome these problems, the purpose program for the first year are 1) to provide training SPSS for islamic students of early childhood educationwho studying in College of Syech Burhanuddin Pariaman, 2) to invite them to be volunteer want to teachingthe science to the islamic students of early childhood education other lectures throughout Islamic Collegesof West Sumatra through the Joint College Community. 3) Prepare Islamic Colleges graduates ready to work in the Research and 4) promote the interest of islamic students of early childhood education to continue their education to the 
departments of science and technology in various leading universities in Indonesia.

\section{METHOD}

The working methods used in the public service are Communitay Based Research[2] by using a mixed method approach[3]. This approach is considered appropriate due to study the problems and acquire a deeper meaning concerning statistical training action program of software application, strengthening the program of SPSS, management of Joint College Communityin the field with Community-Based Research (CBR). Dedication to the community-based research will produce descriptive data in the form of words or the views of the people and observed behavior.

CBR's theme is "Training Statistical Software Application for Islamic student of early childhood education programs". The program provides training SPSS and Amos. First Year Program for the training given to the students are training SPSS for Islamic student of early childhood education programs in the College of Syech Burhanuddin Pariaman. The training was held in the training room of College of Syech Burhanuddin Pariaman. As for the activities carried out at the College of Diniyah Putri Padang Panjang through Joint College Community in West Sumatra.

The target group community service activities are the islamic students of early childhood education who lectures at islamic college in West Sumatra under coordination with Kopertais Region VI West Sumatra province, but for the power of volunteers or volunteer who is assigned as a companion Training Activity SPSS in Higher Education Padang Panjang Diniyah daughter is a student at an Islamic education early childhood STIT-SB which pass a rigorous selection became a trainee and willing to volunteer to be placed on training activities implemented SPSS Joint College Community.

Setting dedication to the communities research were divided into 4 stages[4]. Namely 1) Stage One: Laying Foundation, negotiating with community leaders, local density and Government in this case goverment of Padang Pariaman City along with his team to deliver a pilot project to them and at the same time preparing the technical implementation of activities to establishe a) Steering Commite and their each role in the committee, b) Identify people's perspectives on the research undertaken c) Formulate Schedule of Events according to the field situation and identify Research Objectives. 2) Sechond Phase, namely the planning stage, this stage is to formulate the activities planning form the joint college community that starts with preparing volunteers to conduct the Intensive Training for volunteers candidate who were selected through Selection. 3) Third stage, is collect the data and information related to training activities carried out for 3 days and SPSS Training Event held at the College of Syech
Burhanuddin Pariaman. Then, after the joint college coomunity was done, then do SPSS training free of charge to all students of Islamic education in early childhood program at the College of Diniyah Putri Padang Panjang. The collection of data on two activities include surveys and FGD is to improve the sharpening action and deem necessary in the next training activities. 4) Fourth Stage, namely action and findings which includes negotiations and mobilization of knowledge with the community to evaluate the progress of program and improve technical activities related to share information among teams in the field with a team of Managerial Activities to formulate improvements in activities necessary to accelerate expected outcomes in accordance with the target of statistical application training program for processing quantitative data. After four events this is done, then do a second focus group to follow up the results of activity (pilot project) on the continuation of this program in order to build the next training held in each Islamic College in West Sumatra.

Instruments community service activities are 1) the research team, 2) Observation Sheet, 3) Interview Guidelines 4) Documentation and 5) field records. The technique of collecting data using questionnaires, field observations sheet, and guidelines for SPSS progress assessment and interpretation of SPSS output.

The data analysis technique used is 1) Statistical techniques "distribution frequency" is used to analyze the results of the initial survey, the analysis of the social situation needs will be held the training of statistical software in Islamic College of West Sumatra and the distribution of the frequency of interest trainee after participating in the training activities, 2) qualitative analysis techniques used to analyze the results of observation from the software statistical training activities program by measuring the ability in doing the process of data and interpret of them by reading the SPSS output into a discussion of the quantitative research results. To evaluate the success of participants' in master using SPSS can be tested by measuring students' ability and compare them between before following activities and after attending the activities and simultaneously comparing the activities that can be done (das Sein) with expacted targets (das solen) [5].3) Quantitative analysis technique used to determine the calculated difference test, namely: 1) Prates and post-test results. 2) Test the difference with pre-test and post-test. The process of data analysis is using statistical principles and formulas through $\mathrm{t}$ test and Analysis of Variance (ANOVA). ANOVA is a method to describe the total diversity of the data into components that measure the various sources of diversity. 


\section{FINDING}

\section{A. Community Involvement in the Activity}

From all the process of Publc service with research-based society in 2016 , is not all community members are directly involved. In the process of this action, community involvement can be divided into two functions, namely the function of $\mathrm{CO}$ and functions of SC. In detail number of community members involved in the process of this action is as follows:

\section{TABLE 1. COMMUNITY INVOLVEMENT}

\begin{tabular}{|l|l|c|c|}
\hline No. & Community & SC & CO \\
\hline 1 & Academics Syekh Burhanuddin College & 3 & 3 \\
\hline 2 & Islamic College Research Institute & 5 & 5 \\
\hline 3 & Kopertais-Region VI & 2 & 2 \\
\hline 4 & Practitioners from UNP & 4 & 4 \\
\hline 5 & $\begin{array}{l}\text { Islamic Students of early childhood education } \\
\text { in West Sumatra College }\end{array}$ & \multicolumn{2}{|l|}{} \\
\hline
\end{tabular}

Based on the table above the number of members of the SC in the Joint College Community totaling 16 consisting of three people on the research team of Syekh Burhanuddin College are Reflianto, Elfa Yusra, Misbah Laila, 5 people from the Research Institute of Islamic College coordinator, one of the leaders Kopertais and 1 from practitioners. Meanwhile, the $\mathrm{CO}$ group totaled 14 people consisting of 3 persons of Syekh Burhanuddin Academician, they are is Handriadi, Syukriadi and Nora Afnita, 5 of Islamic Education of West Sumatra, one from Kopertais in the Region VI and one person practitioner and researchers.

\section{B. Workshop}

1. Mapping Forum formation Joint College Communitythrough focus group discussion is facilitated by Syekh Burhanuddin College of Pariaman

This activity is to map the formation of the Joint College Community within Kopertais Region-VI of West Sumatra through FGD by inviting leaders of Kopertais, Research Team in each Islamic College, Local researchers and the research team at College of Syech Burhanuddin Pariaman facilitated by College of Syech Burhanuddin Pariaman in order to speed the mastery of science and improve the quality of quantitative research results among students of Islamic education in the early childhood program in Suamtera West. FGD is done to improve islamic student of early childhood education in the line of SPSS and Amos. To have qualified skill in the data processing of quantitative by using statistical software such as SPSS program, Amos, lisrel and eView. But in this pilot project with more emphasis on SPSS training. This FGD cooperation and build academic authorities of Syekh Burhanuddin College in Pariaman of West Sumatra throughjoint College Community.

Through this FGD, along Kopertais of West Sumatra Region VI is inviting the leaders of Islamic College in West Sumatera, constrtuct Research Team in each Existed Islamic College, local researchers and the research team at Syekh Burhanuddin Pariaman College to establish the joint College Communityproject, is. to work together to build the training program of SPSS for Islamic education students who are studying at early childhood program throughout Islamic Collegess in West Sumatra. The formation of this Joint College Community as the contribution of the academic community is to support the strengthening at the same time to the improvement of the quantitative results study among Islamic student for early childhood education in West Sumatra.

\section{Mapping the Action of joint College Community}

Building a partnership opportunities through Kopertais Region VI of West Sumatra led the entire of Islamic College, , Local researchers and Research Unit from any kind of Islamic Institutions of Syech Burhanuddin Pariamanjointly to implement the training program of SPSS For islamic students in the early childhood educationprogram in West Sumatra, it was agreed to pilot projects in the first y ears is SPSS Training activities conducted in Diniyah Putri Padang Panjang College of West Sumatra Province.

\section{First Event Output of Statistical Software in the Syekh Burhanuddin Pariaman}

Through computer, the quantiative data calculations by using SPSS version 17.0 is known that the average score (mean) of 56.93; mode of 58.00; the middle score (median) of 58.00; and a standard deviation of 3.615. The frequency distribution of pretest scores can be seen in Table 1 below.

TABLE 2. FREQUENCY DISTRIBUTION OF PRE TEST

Pre Test Score

\begin{tabular}{|cc|c|c|c|c|}
\hline & & & & & $\begin{array}{c}\text { Cumulati } \\
\text { ve } \\
\text { vercent }\end{array}$ \\
\hline valid & 50 & 2 & 13.3 & 13.3 & 13.3 \\
& 54 & 2 & 13.3 & 13.3 & 26.7 \\
& 56 & 2 & 13.3 & 13.3 & 40.0 \\
& 58 & 4 & 26.7 & 26.7 & 66.7 \\
60 & 4 & 26.7 & 26.7 & 93.3 \\
& 62 & 1 & 6.7 & 6.7 & 100.0 \\
& Total & 15 & 100.0 & 100.0 & \\
\hline
\end{tabular}


According to the table 2 is known that there are two students who receive pre-test score for each value of 50, 54, and 56. As for the value of 58 there were 4 people and a score of 60 is also 4 people. For the highest score is 62 is only obtained if one person out of 15 trainees who participated as a candidate volunteers.

Based on statistical data can be obtained and presented the acquisition propensity score pre-test category to measure the capability of student as intial master in using SPSS tool as data analysis

\section{TABLE 3. CATEGORY}

\begin{tabular}{|c|c|c|c|c|}
\hline No. & Category & interval & Frequency & $(\%)$ \\
\hline 1 & Low & $<60$ & 10 & 66.7 \\
\hline 2 & Good & $60-79$ & 5 & 33.3 \\
\hline 3 & ssangat Good & $>79$ & 0 & $0: 00$ \\
\hline \multicolumn{3}{|c|}{ amount } & 15 & 100 \\
\hline
\end{tabular}

Based on table 3 above, the pre-test scores of SPSS capabilities of trainees are divided into three category, ie low, good, and excellent. None of the students scored very well with skorr range above 80 . There are $66.7 \%$ of trainees prior knowledge of SPSS is low and only $33.3 \%$ have basic capabilities of SPSS training participants in both categories.

After the training, re-measured the ability of the students in the mastery of statistical software program by using SPSS version 17.0 for data processing to find out the score (mean) of 70,80; mode of 76.00; the middle score (median) of 70,80; and a standard deviation of 6.132. The calculation result can be seen in the attachment. The frequency distribution post-test scores prior knowledge of SPSS participants after the training can be seen in Table 3 below.

TABLE 4. DISTRIBUTION FREQUENCY OF POST-TEST

Post Test Scores

\begin{tabular}{|rr|r|r|r|r|}
\hline & & frequency & Percent & $\begin{array}{c}\text { valid } \\
\text { Percent }\end{array}$ & $\begin{array}{c}\text { Cumulative } \\
\text { Percent }\end{array}$ \\
\hline Valid & 56 & 1 & 6.7 & 6.7 & 6.7 \\
& 64 & 1 & 6.7 & 6.7 & 13.3 \\
66 & 2 & 13.3 & 13.3 & 26.7 \\
68 & 1 & 6.7 & 6.7 & 33.3 \\
70 & 2 & 13.3 & 13.3 & 46.7 \\
72 & 2 & 13.3 & 13.3 & 60.0 \\
74 & 1 & 6.7 & 6.7 & 66.7 \\
76 & 4 & 26.7 & 26.7 & 93.3 \\
80 & 1 & 6.7 & 6.7 & 100.0 \\
Total & 15 & 100.0 & 100.0 & \\
\hline
\end{tabular}

According to the table 4above, it can be seen that there is one participant who has the highest score of 80 , and one person who gets the lowest score 56 . while there are two people from each of the participants who get scored 66, 70 and 72 . Participants scores 76 as much as 4 people.
Based on statistical data obtained can be presented categories propensity score acquisition of SPSS post-test capability Trainees as shown in the following table.

TABLE 5. CATEGORY

\begin{tabular}{|c|c|c|c|c|}
\hline No. & Category & interval & Frequency & $(\%)$ \\
\hline 1 & Low & $<60$ & 1 & 35.29 \\
\hline 2 & Good & $60-79$ & 13 & 50.00 \\
\hline 3 & Very good & $>79$ & 1 & 14.71 \\
\hline \multicolumn{3}{|c|}{ amount } & 34 & 100 \\
\hline
\end{tabular}

Based on Table 5 above, the post-test scores of Participants are divided into three intervals, ie low, good, and excellent. Participants who earn a high score (greater than 79) as much as 1 student, was the lowest score is also 1 with a value of 56 and as many as 13 participants have mastered a good quantitative data processing.

\section{Data Comparison between Pre Test and Post-test among Participant in Staistical Software Training in College of Syech Burhanuddin Pariaman}

The data comparison between Pre Test and Post Test in the Training Event of Sofrtware Analisys in the college of Syekh Burhanuddin Pariaman.

TABLE 6 COMPARISON BETWEEN PRE-TEST AND POST-TEST

\begin{tabular}{|c|l|c|c|}
\hline No. & \multicolumn{1}{|c|}{ Statistics } & Pre-test & Post-test \\
\hline 1 & N & 15 & 15 \\
\hline 2 & Top scores & 62 & 80 \\
\hline 3 & lowest score & 50 & 56 \\
\hline 4 & mean & 56.93 & 70.80 \\
\hline 5 & Mode & 58.00 & 76 \\
\hline 6 & median & 33.00 & 72.00 \\
\hline 7 & standard Deviation & 3615 & 6132 \\
\hline
\end{tabular}

From Table 6 above, then can be compared between the scores pre-test and post-test Participants capability in Statistical Training Activity Analisys at the college of Syekh Burhanuddin Pariaman.

In the pre-test group was 63 for the highest score and 50 for lowest score. The increase occurred in the post-test with the highest score of 80 and the lowest score 56 .. This shows an increase in average scores between the control class and experiment class after participants follow the training of Statistical training Program at Syekh Burhanuddin Pariaman. It showed no difference in the average value significantly between the pre-test and post-test.

\section{Pre Test and and Post-test Participant who follow the Training in College of Syech Burhanuddin Pariaman with t-test}

The results of t-test performed showed the ability to master the quantitative data processing by using SPSS program exhibited significantly increased where the difference in the ability of mastering SPSS 
for data processing of various quantitative studies before training with after the training. As seen in tabel.6 below.

\section{TABLE 7 HYPOTHESIS TESTING INDEPENDENT T TEST}

\begin{tabular}{|c|c|c|c|c|}
\hline Data & t-hitung & Sig & Df & Tahap \\
\hline $\begin{array}{l}\text { Perbandingan } \\
\text { Pre-Test and } \\
\text { Post-Test }\end{array}$ & 7.545 & 0.000 & 28 & $\begin{array}{l}0.000<0,05 \\
\text { Signifikan }\end{array}$ \\
\hline
\end{tabular}

There are differences in the ability of mastering SPSS for data processing of various types of quantitative research between before and after training for 15 volunteers who are trained to be a companion to the program of Training Program of SPSS with the Joint College Community held in the Campus College of Syech Burhanuddin Pariaman has been able to increase the Traffic SPSS student mastery of Islamic education in the early childhood quantitative reearch of data processing of various types of data analysis parametric and non-parametric.

\section{Output of two Activity Training in College Diniyah Putri Padang Panjang}

Pre Test results for 40 trainees at the College of Diniyah Putri Padang Panjang is a mean of 49.75; mode of 54.00; the middle score (median) 51.00; and a standard deviation of 7.178. The frequency distribution of pre-test scores of trainees SPSS Diniyah Putri in Higher Educationfield The length can be seen in the table 8 below.

\section{TABLE 8 FREQUENCY DISTRIBUTION PRE-TEST IN THE} COLLEGE OF DINIYAH PUTRI PANAJNG

\begin{tabular}{|c|r|r|r|r|}
\hline & frequency & Percent & $\begin{array}{c}\text { valid } \\
\text { Percent }\end{array}$ & $\begin{array}{c}\text { Cumulative } \\
\text { Percent }\end{array}$ \\
\hline Valid 34 & 1 & 2.5 & 2.5 & 2.5 \\
36 & 1 & 2.5 & 2.5 & 5.0 \\
38 & 2 & 5.0 & 5.0 & 10.0 \\
42 & 2 & 5.0 & 5.0 & 15.0 \\
44 & 2 & 5.0 & 5.0 & 20.0 \\
46 & 8 & 20.0 & 20.0 & 40.0 \\
48 & 1 & 2.5 & 2.5 & 42.5 \\
50 & 3 & 7.5 & 7.5 & 50.0 \\
52 & 5 & 12.5 & 12.5 & 62.5 \\
54 & 11 & 27.5 & 27.5 & 90.0 \\
56 & 1 & 2.5 & 2.5 & 92.5 \\
64 & 1 & 2.5 & 2.5 & 95.0 \\
66 & 2 & 5.0 & 5.0 & 100.0 \\
Total & 40 & 100.0 & 100.0 & \\
\hline
\end{tabular}

According to the table 8 above, it is known that there are 11 students who scored 54 , then 8 people are getting the value 46, 5 people who get the value of 52 . The lowest score was 34 and the highest value of 66 obtained by the two participants.
Based on statistical data obtained can be presented category acquisition propensity score pretest of participant capability to master the SPSS can be seen in the following table.

\section{TABLE 9. CATEGORY STUDENT IN THE COLLEGE OF DINIYAH PUTRI PADANG PANAJNG}

\begin{tabular}{|c|c|c|c|c|}
\hline No. & Category & interval & Frequency & $(\%)$ \\
\hline 1 & Low & $<60$ & 37 & 92.5 \\
\hline 2 & Good & $60-79$ & 3 & 7.5 \\
\hline 3 & ssangat Good & $>79$ & 0 & $0: 00$ \\
\hline \multicolumn{3}{|c|}{ amount } & 40 & 100 \\
\hline
\end{tabular}

According to the table 9 above, the pre-test scores of beginning trainees who following the training program at the college of Diniyah Putri Padang is divided into three intervals, ie low, good, and excellent. None of the students scored very well with skorr ranges are $7.5 \%$ above 80 . The initial capabilities of SPSS trainees is good, while the majority of students have not mastered the quantitative data processing by using SPSS is as much as $92.5 \%$

Once the training is given, then the value of the Post-test trainee capability by using assessment scale format. Subject post-test as many as 40 participants. From the post-test produced the highest score was 84 and the lowest score is 64 scores (mean) of 71.55; mode of 72.00; the middle score (median) of 72.00; and a standard deviation of 5.174. The calculation result can be seen in the attachment. The frequency distribution post-test scores for intial trainee of SPSS who follow the SPSS training program in the college of Diniyah Putri Padang Panjang can be seen in the following table.

TABLE 1OPOST-TEST AFTER FOLLOWING TRAINING AT THE COLLEGE OF DINIYAH PUTRI PADANG PANJANG

\begin{tabular}{|rr|r|r|r|r|}
\hline & & & & valid & Cumulative \\
frequency & Percent & Percent & Percent \\
\hline valid & 64 & 5 & 12.5 & 12.5 & 12.5 \\
& 66 & 3 & 7.5 & 7.5 & 20.0 \\
& 68 & 6 & 15.0 & 15.0 & 35.0 \\
& 70 & 5 & 12.5 & 12.5 & 47.5 \\
72 & 7 & 17.5 & 17.5 & 65.0 \\
74 & 4 & 10.0 & 10.0 & 75.0 \\
76 & 3 & 7.5 & 7.5 & 82.5 \\
78 & 3 & 7.5 & 7.5 & 90.0 \\
80 & 3 & 7.5 & 7.5 & 97.5 \\
84 & 1 & 2.5 & 2.5 & 100.0 \\
& Total & 40 & 100.0 & 100.0 & \\
\hline
\end{tabular}

Based on table 10, it can be seen that there are five participants have a value that is 64 and 70 who are in the good category, six people who have values 68 and 7 who scored 72 in both categories. Meanwhile there are 4 people who get score of 74 and 
3 people are getting the value $66,76,78$, and 80 and only one person who gets the highest score 84 with categorization as follows:

TABLE 11. CATEGORIES PARTICIPANT CAPABILITY AT THE COLLEGE OF DINIYAH PUTRI PADANG PANJANG

\begin{tabular}{|c|c|c|c|c|}
\hline No. & Category & interval & Frequency & $(\%)$ \\
\hline 1 & Low & $<60$ & 0 & $0: 00$ \\
\hline 2 & Good & $60-79$ & 36 & 90.00 \\
\hline 3 & Very good & $>79$ & 4 & $10: 00$ \\
\hline \multicolumn{3}{|c|}{ amount } & 34 & 100.00 \\
\hline
\end{tabular}

According to the table 11, the post-test scores of Participants are divided into three intervals, ie low, good, and excellent. Participants who earn a high score is a score greater than 79 as many as four students (10\%). None of the participants who get score below 60, which means none of the students who received the lowest score. Most participants get a value in the range of 60-79 as many as 36 people (90\%), which showed an increase in the ability of mastering SPSS by trainees after the following the SPSS training is guided by quantitative experts for research analysis and statistics.

\section{Data Comparison between Pre and Post-test in the SPSS Training College PutriPadang Panjang}

The comparison scores of pre-test and post-test and post test capability of Participants in using SPSS program and follwoing a Statistical Training Activity Analisys Sofrtware Diniyah Putgri Padang Panjang

\section{TABLE 12 COMPARISON PRE-TEST AND POST-TEST OF PARTICIPANTS CAPABILITY}

\begin{tabular}{|c|l|c|c|}
\hline No. & \multicolumn{1}{|c|}{ Statistics } & Pre-test & Post-test \\
\hline 1 & N & 40 & 40 \\
\hline 2 & Top scores & 66 & 84 \\
\hline 3 & lowest score & 34 & 64 \\
\hline 4 & Mean & 49.75 & 72.00 \\
\hline 5 & Mode & 54 & 72.00 \\
\hline 6 & Median & 51.00 & 71.55 \\
\hline 7 & standard Deviation & 7178 & 5,174 \\
\hline
\end{tabular}

From table 12 above, scores can be compared between pre-test and post-test of Participants capability follows in intial master of SPSS program in Statistical Training Activity at Diniyah Putri Padang Panjang seen the highest pre-test score was 66 and the lowest was 34 . The increase occurred in the post-test was 84 with the highest score and the lowest score 64 .. this shows an increase in average scores between the participants ability of SPSS program before and after following of SPSS Program at the college of Diniyah Putri Padang Panjang. It showed no difference in the average value significantly between the pre-test and post-test.

\section{T-Test of Pre Test and Post-test Participant of SPSS Program in Joint College Community at the College of Diniyah Putri Padang Panjang.}

The test results of independent $t$ test known differences in mastery of SPSS before and after following the training of SPSS Program in the Joint College Community program at the college of Diniyah Putri Padang Panjang as shown in the table below:

TABLE 13 HYPOTHESIS TESTING INDEPENDENT T TEST AT THE COLLEGE OF DINIYAH PUTRI PADANG PANJANG

\begin{tabular}{|l|r|c|c|l|}
\hline Data & t-hitung & Sig & Df & Tahap \\
\hline $\begin{array}{l}\text { Perbandingan } \\
\begin{array}{l}\text { Pre-Test and } \\
\text { Post-Test }\end{array}\end{array}$ & 15.582 & 0.000 & 78 & $\begin{array}{l}0.000<0,05 \\
\text { Signifikan }\end{array}$ \\
\hline
\end{tabular}

The output results of SPSS version 17.0 show the significance level of $0.000<0.05$, which means that there are differences in the participants ability of SPSS for data processing for various quantitative research between before and after following the training of SPSS in Joint College Community. About 40 participants of training at the College of Diniyah Putri Padang Panjang has been able to increase their ability in understanding of SPSS program for analysis the data processing in qualitative research model both parametric and non-parametric analysis.

\section{DISCUSSION}

Training applied statistical software analysis such as SPSS, AMOS, lisrel and Eveiw considered highly strategic in facilitating students to improve their ability in doing the data processing[6] for quantitative research model and quality of student research while completing their degree studies at the College of Islam in Indonesia, especially in West Sumatra, but it also provides their clinics in the final project (thesis). Associated with data processing for quantitative research that requires complex statistical analysis that can be done with the program applied statistical analysis by using software such as SPSS [7], AMOS, lisrel and Eveiw. But for this first year of training program provided to students of Islamic for early childhood education came from Private Islamic College all arround West Sumatra to following the training of SPSS. Given training limited to funding and time in the execution of community service activities. From the results of training can be obtained the accelerated process of student's mastering in the processing of quantitative data by using SPSS Program especially for islamic students for Early Childhood Program which involved in the Joint College Community Program. This result shows that there are significant difference between participants ability in processing the qualitative data by using 
SPSS between before and after following the activity of SPSS training.

At the first training, is to prepare personnel volunteer to mentor in training SPSS later throughout in West Sumatra where the first year is the college as partner in this program thorugh Joint College Community leads to organize the next training in the College of Diniyah Putri Padang Panjang in West Sumatra Province.

At the first training which trained 15 people elected who already have a basic processing of quantitative data by using SPSS, visible progress exhibited significantly between before and after folloing the training by several indicators of assessment research type and scale of the data, the selection of analysis tools, data input up to reading of the output from various types of analysis tools in SPSS program such as correlation, regression, validity, reliability, normality, homogeneity, and the reading of the output data both parametric and nonparametric tests for example Bivariat, Independent $\mathrm{t}$ test, paired sample t-test, wilcoxson, etc. obtained an increase the students ability who attend the training and get ready to be Volunteer to the next training Program of SPSS which held through Joint College Community in the college of Diniah Putri Padang Panjang. The result in the next traing also showed that threre was significant difference of participant master in SPSS Program between their prior knowledge before entering the training and after entering the training with an average score of the ability of $33.1 \%$ increase to $50 \%$ who have a good capability plus $14.7 \%$ which

Meanwhile, in the second activity is the training of SPSS with the Joint College Community held in the College of Diniyah Putri Padang Panajng show a rise of islamic student ability in mastering of data processing by using SPSS. It exhibited significantly from participants when compared with before and after following the training to do the processing of quantitative data research by using SPSS program. Comparison of the scores between pre-test and posttest as much as $92.5 \%$ where islamic student ability in using SPSS Program in the processing of quantitative research data increased to $90 \%$ after following the program and plus $10 \%$ of participants were able to achieve excellent in analysis of quantitative research data and none of the participants who had not yet mastered in using the SPSS program after following the training of SPSS together through Joint College Community in the college of Diniah Putri Padang Panjang. It means that the training activities applied statistical software analysis such as SPSS has been able to accelerate the mastery of islamic student in the field of science, especially the science of statistics and methodology of quantitative research on them for early childhood education in West Sumatra through community service activities, whether conducted in cooperation between the islamic college which lead by STIT Syekh Burhanuddin and Islamic College institutions of Kopertais for Region VI in West Sumatra.

For the implementation of training in applied statistical analysis of software program through Joint College Community is very attention and enthusiasm of the islamic students as trainees. However, due to limited amount of money, this training can not recruit participants too much, only 40 people.

The results showed that an accelerated activity of mastering SPSS have increased in doing the data processing of quantitative research by comparison of the their improvement significantly. This is evident from the average value of the earliest known from the pre-test were given to the participants reflect initial knowledge about the mastery of quantitative data processing by using a variety of analysis tools contained in the SPSS program included in the low category. This fact identifies that the training activities in the statistical software analysis in program of Joint College Community for private college of Islamic students in West Sumatra in order to accelerate the mastery of science and technology, especially for improving the quality of islamic student for early childhood education program who need the ability of SPSS program in their research.

After following the applied statistical analysis software program through Joint College Community, participants showed an average increase in value of 49.75 becomes 7:00 .. Measured from improved scores as an indicator mastery in running the assessment tool of SPSS in selecting the appropriate type of research and analysis of the quantitative data, input Data up to the reading of the output data from various types of SPSS analysis tools such as correlation, regression, validity, reliability, normality, homogeneity, and the reading of the data output as Bivariat non-parametric test, Independent t-test, paired sample t-test, wilcoxson, etc. Through joint the training of SPSS in the Joint College Community showed that islamic student abilityin using SPSS have signficant increased about $82.5 \%$ (from an average value of 7.5 in the pre test become 90.0 on the posttest) with the qualification of the low category before training become haigh category after training.

Happening the increasing score of mastering the SPSS program by participants after following the training of SPSS together with the Joint College Community because the participants were very enthusiastic and earnest training, in addition, participants also equipped with a module that has been prepared to facilitate them to learn independently and to learn directly from cases given to them during the training. In addition the strengthen simulation also encourages all participants can master the SPSS program for data processing of quantitative research. Indeed, it is an advantage of SPSS training method was designed by the Joint College Community for students of Islamic education for the early childhood education program throughout all Provate Islamic College in Sumatra west and the 
challenge for the next activity to achieve the next training success criteria are much better on the activities of the following years.

The implications of the findings and discussion of the training of SPSS in program Joint College Community is that the training can help islamic student to accelerate their mastery in using SPSS for data processing of quantitative research in their final project latter, but this capability continues to be sustainable, it needs continuous training nature. The more often the training is done on the same subject, it is also greater success. For that reasong the training of SPSS Program togehter with Joint College Community was followed by intensive mentoring process in the implementation of the actual training in the field. It is very important to do, because the implementation of SPSS training in program of Joint College Community is one effective way to facilitate islamic students in accelerating their mastery in using SPSS program for data processing of quantitative research that is useful for their ecomplishmen of their final thesis them in order to improve their academic quality become the best graduates who enable to fight the hard competition in the age of globalization era.

\section{CONCLUSION}

The conclusion of this study is that the activities of the Joint Madrasah Community was instrumental once as a forum of cooperation between madrasah and universities to sovel problem of students' life skills by strengthening madrasah curriculum. By this activity, it will easy to put some volunteer teacher in providing local content of life skills material for students. Joint Madrasah Community held in MAN Padusunan and MAS Darul Ulum has reinforced the power of students' life skills in various areas of thier interest such as Kalligrafi and Public Speaking. It has given birth to eight cadres of public speaking and 7 cadres for calligraphy became voluneter to continue the next program. Increasing of public speaking skills is in the good category where before training (29\%) and after training (64.71\%). Due the strengthening of students' calligraphy skill is also in good category between before training (15\%) and after training (70\%).

\section{References}

[1] Reflianto, et al,. Research Lecturer. College of Syech Burhanuddin Pariaman. Mastery Evaluation Methodology Applied Sciences Research and Technology Students Islamic education early childhood College of Syech Burhanuddin Pariaman. 2014

[2] Travers R, Flicker S. Ethical issues in community based research. In: Urban HealthCommunity-Based Research Series Workshop. Wellesley, MA; 2004

[3] Creswell W. John.. Research Design Pendekatan Kualitatif, Kuantitatif, danMixed. Yogyakarta : Pustaka Pelajar.2013

[4] O'Fallon LR, Dearry A. Community-based participatory research as a tool to advanceenvironmental health sciences. Environ Health Perspect. 2002;110:155-159.

[5] Sugiyono. Metode Penelitian Pendidikan Pendekatan Kuantitatif, Kualitatif, dan R\&D.Bandung: Alfabet..2013.

[6] Dhyah Setyorini, M.SI, dkk, 2010. Pelatihan Pengolahan Data Stgatistik dengan Menggunakan SPSS Bagi Mahasiswa Akuntasi Untuk Meingkatkan Kualitas Karya Ilmiah

[7] Sheridan J Coakes, Lyndall Steed, Clara Ong. SPSS Version 17.0 For Window Analysis Without Anguish. 2010. 